\title{
RECONSIDERATION OF SUBROGATIVE RIGHTS OF THE MILLER ACT PAYMENT BOND SURETY
}

THE owner in private construction contracts, in order to secure timely performance from the contractor and to protect the improvement from the liens of unpaid laborers and materialmen, ${ }^{1}$ usually contracts for retention of a percentage of progress payments. This retained fund, known as retainages, becomes due and payable to the contractor upon acceptance of performance and release of all claims. ${ }^{2}$ Combined or separate performance and payment bonds, ${ }^{3}$ required by law in some states ${ }^{4}$ and customary on larger projects elsewhere," provides an additional means of protection for the owner and suppliers. Since satisfactory performance and payment of laborers and materialmen is a condition precedent to disbursement of the fund, the owner upon default by the contractor may expend the retainages to satisfy the claims of suppliers or to complete performance. ${ }^{6}$ Where a payment bond is required, the surety, if

1. Mechanics' lien laws, designed to secure payment of suppliers by providing a lien on the structure to which they have contributed superior to the claims of the contractor's creditors, have been enacted in all states. See Comment, 68 YaLE L.J. 138 (1958). See also United States v. Holman Lumber Co., 206 F.2d 685, 690, reaff'd on rehearing, 208 F.2d 113 (5th Cir. 1953) ; In re Taylorcraft Aviation Corp., 168 F.2d S08, \$11 (6th Cir. 1948); United States v. Griffin-Moore Lumber Co., 62 So. 2d 589, 590 (Fla. 1953) ; MacLachlan, Bankruptcy 234 (1956); Cusharan, Credir Factors in Constructron 1 (1951); Kerrigan, The Surety As Competing Claimant to Contract Funds, 24 Ins. Counser J. 34 , 35 (1957).

2. See Gee, Agent's Bonding Guide 150-51 (2d ed. 1948) [hereinafter cited as Gee] ; American Institute Of Certified Public Accountants, Auditing In The ConstrucTION INDUSTRY 15 (1959). Often, the sum will not be released until the period for filing liens against the improvement has lapsed. The contractor, however, may request premature release of the withheld moneys; but when the contract is bonded, the consent of the surety is usually required. See Gre 150-51.

3. Combined coverage is available at no additional expense. SURETy Assoctation of America, Bonds of Suretyship 20-21 (1959); Gee 138; Mackall, Principles of SureTy UndERwRiting 123 (1951) [hereinafter cited as MackalL]. See AIA approved standard form, Doc. No. A-311, Performance and Payment Bonds (1958 ed.) (separate bonds) set forth at Surety Association of America, op. cit. supra at 32-39; Aetna Casualty and Surety Company standard combined performance and payment bond, form S-1713-B.

4. E.g., La. Rev. Stat. tit. 38, $\$ 2241$ (1951). See Cushman, Eonds on Public Works 600 (1960), reprinted from Crentr Manual of Commercial Laws (1960 ed.); Tomson, IT's The LAW! 110-11 n.2 (1960).

5. The existence of mechanics' lien laws, effectively transforming the owner's property into a "real surety," created a need for surety bond protection in private construction. See Surety Association of America, op. cit. supra note 3, at 7-9, 19-24; Cushman, op. cit. supra note 1, at 3, 9-16; Texas AGC Chapters Executive Council, So You Want To Be A Successful Contractor 8-13 (1957).

6. Cf. Scarsdale Nat'1 Bank \& Trust Co. v. United States Fid. \& Guar. Co., 264 N.Y. 159, 190 N.E. 330 (1934) ; Stanton v. Babor-Comeau \& Co., 168 Misc. 190, 6 N.Y.S.2d 231 (Sup. Ct. 1938), aff'd, 260 App. Div. 831, 22 N.Y.S.2d 427 (1940). See Annot., 107 A.L.R. 960 (1937). 
called upon, may satisfy the twofold obligations of the defaulting contractor: to provide the owner with an unencumbered structure and to meet the legitimate claims of suppliers. If such contractor is bankrupt, the retainages held by the owner constitute the surety's major source of salvage ${ }^{\tau}$ and may be reached through subrogation. ${ }^{8}$ Under traditional principles of subrogation, where a person not as a volunteer and in the absence of outstanding superior equities pays a debt of another, that person is substituted to all rights and remedies of the creditor as if the debt had never been paid. ${ }^{9}$ Because the owner, having the right to protect himself from the consequences of default, may apply the fund to unpaid claims, the surety is subrogated to this right in the fund. ${ }^{10}$ Title to

7. Salvage, a trade term, encompasses the various forms of recovery-reimbursement, exoneration, subrogation, assignment, self-help, and indemnity - used to offset losses under the bond. Its importance cannot be underestimated, for without it surety rates would be substantially higher. BackMran, SURETy RATE-MARING 34-35, 90-91 (1948) [hereinafter cited as BackMan] ; CRIsT, Corporate SuRetyship 122-23 (1950) [hereinafter cited as CRIST].

Under general principles of suretyship, the contractor-principal impliedly contracts to exonerate his surety by fulfillment of the obligations of the contract. See Finkelstein v. Keith Fabrics, Inc., 278 F.2d 635 (5th Cir. 1960) ; Western Cas. \& Sur. Co. v. Biggs, 217 F.2d 163 (7th Cir. 1954); Kelleam v. Maryland Cas. Co., 112 F.2d 940 (10th Cir. 1940); Falvey v. Foreman-State Nat'l Bank, 101 F.2d 409 (7th Cir.), cert. denied, 307 U.S. 632 (1939) ; Danais v. DeMatteo Constr. Co., 102 F. Supp. 874 (D.N.H. 1952). See Howell, Exoneration of Surety, 22 INs. Counser J. 49 (1955); Smedley, Indennification Before Payment-A Neze Remedy For the Surety?, 40 Ky. L.J. 167 (1951).

In the absence of exoneration, the surety is owed reimbursement to the extent of loss by the contractor. American Sur. Co. v. Haynes, 91 Fed. 90 (C.C.E.D. Mo. 1898) ; Finkelstein v. Keith Fabrics, Inc., supra. See Witherspoon, Surety's Salvage and Subrogation, 25 Ins. Counsel J. 168 (1958); Miller \& Ireton, Problem of Surety in Completing Contract Over Protest of Principal, 22 Ins. Counsel J. 472, 473 (1955); Smedley, stipra at 167; MACKall 15.

But, if the defaulting contractor is insolvent or in bankruptcy, as is often the case, exoneration and reimbursement will be inadequate remedies. See Mansfield \& McCahan, Clains Under Contract Bonds, 21 INs. CounseL J. 265, 266-71 (1954).

8. Upon satisfaction of the contractor-principal's debt, the surety may be subrogated to the position of: The creditor whom he pays. E.g., Munsey Trust Co. v. United States, 67 F. Supp. 976 (Ct. Cl. 1946), rev'd on other gronnds, 332 U.S. 234 (1947) ; see SrmpSON, SURETYSHIP 205-23 (1950). The owner. See notes 9-10 infra and accompanying text. And the defaulting contractor. See Cooney, Practical Problems Facing Surety on Bond of a Defaulting Public Contractor, 21 Ins. Counsec. J. 145 (1954); Haas, The Corporate Surety and Public Construction Bonds, 25 Gro. WASH. L. REv. 206, 211 (1957) ; but see Kerrigan, supra note 1 , at 36 .

Additionally, the surety may assert rights under the indemnity agreement and assignment universally present in the bond application. See Cooney, supra at 145; Haas, supra at 220 ; MACKall 16.

9. Home Owners' Loan Corp. v. Sears, Roebuck \& Co., 123 Conn. 232, 238, 193 At1. 769, 772 (1937).

10. See note 6 supra. The retainage is subject to forfeiture for nonpayment of suppliers, as well as under default in performance, because the payment is an implied obligation of the contractor under the contract and both bonds, even where the primary contract is silent as to the duty of the contractor to pay suppliers. Cf. In re Scofield Co., 215 Fed. 45 (2d Cir. 1914). 
the fund never passing from the owner, the surety, as his subrogee, has a superior claim to all other claimants, ${ }^{11}$ including the contractor's trustee in bankruptcy. ${ }^{12}$

The subrogative salvage rights of a surety suffering loss under public construction contracts, however, are not so clear. Because the Government has no direct contractual obligation to pay laborers and materialmen, ${ }^{13}$ and since its structures are immune from lien, ${ }^{14}$ it, unlike the private owner, need be directly concerned only with damages arising out of default in performance which are adequately covered by the performance bond. ${ }^{15}$ Though the Government

11. The surety's claim is superior to that of banks asserting rights under assignments obtained from the contractor upon loan of moneys. See, e.g., Lacy v. Maryland Cas. Co., 32 F.2d 48 (4th Cir. 1929); In re Zaepfel \& Russell, 49 F. Supp. 709 (W.D. Ky. 1941), aff'd sub. nom. Farmer's State Bank v. Jones, 135 F.2d 215 (6th Cir. 1943) (per curiam); Moran v. Guardian Cas. Co., 76 F.2d 438 (D.C. Cir. 1935) ; Scarsdale Nat'l Bank \& Trust Co. v. United States Fid. \& Guar. Co., 264 N.Y. 159, 190 N.E. 330 (1934). See Note, 30 Iowa L. REv. 568, 572-73 (1945); Kerrigan, supra note 1, at 36-37, 39; Cooney, supra note 8, at 147-48; SIMPSON, SuRETXSHIP 211-12 (1950); but see River Junction v. Maryland Cas. Co., 133 F.2d 57 (5th Cir. 1943), criticized in Note, 42 Mrcr. L. Rev. 174 (1943).

The surety's rights are also superior to those of the United States where its lien predates the attaching of the federal claim. E.g., Central Sur. \& Ins. Corp. v. Martin Infante Co., 272 F.2d 231 (3d Cir. 1959) ; Fidelity \& Deposit Co. v. Housing Authority, 241 F.2d 142 (2d Cir. 1957) ; American Sur. Co. v. Municipal Housing Comm'n, 63 F. Supp. 486 (W.D. Ky. 1945), aff'd sub. nom. Glenn v. American Sur. Co., 160 F.2d 977 (6th Cir. 1947) ; Aetna Cas. \& Sur. Co. v. United States, 4 N.Y.2d 639, 152 N.E.2d 225 (1958). See Kerrigan, supra note 1, at 42-46. Compare United States v. Ball Constr. Co., 355 U.S. 587 (1958) (per curiam), where a surety unsuccessfully claimed the contract fund as against federal tax liens because of a loss the surety sustained on another contract.

12. E.g., Danais v. DeMatteo Constr. Co., 102 F. Supp. 874 (1952) (subcontractor's trustee against prime contractor on federal job). See Comment, 50 Nw. U.L. REv. 541 (1955); Note, 17 U. PItT. L. Rev. 712 (1956); Haas, supra note 8, at 221. But see Shapiro v. Royal Indem. Co., 224 F.2d 89 (3d Cir. 1955).

13. See the federal construction contract, Standard Form No. 23, 41 U.S.C. App., Rules \& Regs. $\$ 54.13$ (1958) and the new Standard Form No. 23A, effective July 1, 1961, 26 Fed. Reg. 1050-51 (1961) ; United States v. Munsey Trust Co., 332 U.S. 234, 241 (1957) ; Phoenix Indem. Co. v. Earle, 218 F.2d 645 (9th Cir. 1955); National Sur. Corp. v. United States, 133 F. Supp. 381 (Ct. Cl.), cert. denied, 350 U.S. 902 (1955).

14. Equitable Sur. Co. v. McMillan, 234 U.S. 448, 455 (1914) ; United States v. Ansonia Brass \& Copper Co., 218 U.S. 452 (1910) ; Hill v. American Sur. Co., 200 U.S. 197, 203 (1906) ; Armstrong v. United States, 169 F. Supp. 259 (Ct. Cl. 1959); National Sur. Corp. v. United States, supra note 13.

15. The surety may pursue two courses of action upon the contractor's default in performance. It may waive its right of completion and, liable solely under the bond, limit its possible loss to costs of completion up to the penal sum of the bond. See, e.g., Massachusetts Bonding \& Ins. Co. v. United States, 97 F.2d 879 (9th Cir. 1938) ; Board of Education v. Maryland Cas. Co., 27 F.2d 20 (3d Cir. 1928) ; Pennsylvania Fire Ins. Co. v. American Airlines, Inc., 180 F. Supp. 239 (E.D.N.Y. 1960). See also Mackarl 12. Since the Government advertises for bids and relets the completion contract to the lowest bidder, the surety will not have to assume the burden of maintaining the defaulting contractor's organization or managing and supervising the subsequent contractor's operations, the dangers of being subject to the known and unknown indebtedness of the defaulting contrac- 
had no legal obligation to acknowledge the claims of laborers and materialmen, Congress was unwilling to leave such claimants with no more than a direct contractual action against the defaulting contractor, for in the event of the latter's insolvency they would be deprived of a secured remedy. ${ }^{16}$ The Heard Act ${ }^{17}$ was thus passed to afford laborers and materialmen more adequate protection. ${ }^{18}$ Its successor, the Miller Act, ${ }^{19}$ presently requires as a condition of award of a public contract, besides the execution of a performance bond, a separate payment bond which provides for prompt payment of all persons supplying labor and material on federal construction projects. ${ }^{20}$ Thus, as in the

tor, and, most importantly, the risk of opening itself to unlimited liability in excess of the face amount of the bond. See Mansfield \& McCahan, supra note 7, at 267-70.

Or the surety may elect to complete the contract, providing in its "take-over" contract with the United States for payment of the retainages upon completion. See 31 DECs. CoMrP. GEN. 103 (1951). Since the surety's liability is no longer measured by the penal sum of the bond, but, rather, according to the terms of the "take-over" contract, it assumes total liability for all costs of completion. See, e.g., Houston Fire \& Cas. Ins. Co. v. E. E. Cloer Gen'l Contractor, Inc., 217 F.2d 906 (5th Cir. 1954). It will therefore consider its choice carefully. See Mansfield \& McCahan, supra note 7, at 266-72.

Often the surety will attempt to conceal its role as the performing force in completion of the contract in order to avoid the usual increase in costs exacted from the "fat cat." Purporting to maintain the defaulted contractor's operations without change, it arranges with the contractor's bank for an "open" or "no-balance" account to be held in the contractor's name. As expenses are incurred, the superintendent on the job informs the surety company of their amount and character and, upon approval, draws the required amount from the "no-balance" account. The bank, having arranged with the surety for a "suspensory" account, charges the approved draft of the superintendent against the latter account, depositing the amount of the draft in the "no-balance" account. In this manner, not only is the role of the surety hidden, but the funds disbursed on the contract are not subject to attachment.

16. United States ex rel. Sherman v. Carter, 353 U.S. 210 (1957) ; Belknap Hardware \& Mfg. Co. v. Ohio River Contract Co., 271 Fed. 144 (6th Cir. 1921). See Note, 30 Iowa L. REv. 568, 570 (1945) (similar incentive in state bond enactments).

17. 28 Stat. 278 (1894), as amended, 33 Stat. 811 (1905).

18. The Heard Act, 28 Stat. 278 (1894), as amended, 33 Stat. 811 (1905), required as a condition of the award of a public contract a single bond securing to the United States faithful performance of the contract and prompt payment of all persons supplying labor and material in the prosecution of the work. The unitary bond was in effect two instruments, one securing to the Government the performance of the contractor's obligations towards it, and the second protecting materialmen and laborers. Equitable Sur. Co. v. United States, 234 U.S. 448 (1914) ; United States v. Massachusetts Bonding \& Ins. Co., 18 F.2d 203 (6th Cir. 1927); United States v. National Sur. Co., 92 Fed. 549 (8th Cir. 1899). This was superseded in 1935 by passage of the Miller Act, 49 Stat. 794 (1935), 40 U.S.C. $\$ 270$ (1958), amended, 73 Stat. 279 (1959), 40 U.S.C.A. $\$ 270$ (1960 Supp.).

Prompted by the same incentive, all states, either by express legislation or as a matter of policy, now require some form of bond protection for laborers and materialmen. CusEMAN, op. cit. supra note 4 , at 597.

19. 49 Stat. 794 (1935), 40 U.S.C. $§ 270$ (1958), amended, 73 Stat. 279 (1959), 40 U.S.C.A. § $270 \mathrm{~b}$ (1960 Supp.).

20. 49 Stat. 794 (1935), 40 U.S.C. \& 270 (a)(1)-(2) (1958). Though the Heard and Miller Acts are substantially the same, the two bond system of the latter, in addition to curing the technical defects of the former's unitary bond, provides instruments of 
private field, when the surety is properly called upon to fulfill the defaulting contractor's obligations to suppliers, the surety, asserting subrogative rights through either the creditors paid or the Government, will look to the retainages as its most valuable source of salvage. If the contractor is bankrupt, his trustee in bankruptcy will oppose this claim. Such trustee will argue that the laborers and materialmen, being limited to an action upon the payment bond, have no legally enforceable rights to the retainages against the Government and thus are mere general creditors. ${ }^{21}$ Moreover, the Government has no contractual right to retain or use the fund as security for the payment of claims arising from labor and material contracts to which it is not privy. ${ }^{22}$ Consequently, the surety is subrogated to nothing.

Any superiority of claim to the retainages that the trustee in bankruptcy may assert over the Miller Act payment bond surety must be based on the fortuity of the status of the bankrupt as a contractor on public work rather than on private projects, because the distinctions urged by the trustee are ultimately founded on the traditional immunity of the Government from liens on its structures. But the assumption of a need for Government immunity from liens on withheld funds is only meaningful where the Government has a claim of its own to set-off; for in that case, the Government possesses an interest which the immunity serves to protect. Where the Government holds the funds as a stakeholder, however, the claims of the surety as subrogee are not asserted against the United States, since the claim in no way subjects the Government to liability beyond the amount admittedly due and owing to somebody. ${ }^{23}$ Favoring the claims of the trustee in bankruptcy to retainages will in effect constitute a windfall to general creditors unavailable in the private field. ${ }^{24}$ It would, furthermore, appear undesirable to create such disparate results between public and private construction contracts. In both, the surety and suppliers contribute to the creation of the funds sought by the trustee in bankruptcy for the benefit of general creditors, claimants wholly unconnected with the productive activities underlying its creation. ${ }^{25}$ Moreover, if the cost of private and public bonds is to remain substantially similar, the risks of the surety must be equivalent in both fields. Since subrogation is a prime element in the salvage procedure ex-

greater flexibility. Cushiran, op. cit. sipra note 1, at 2; Surety Association of Adrerica, op. cit. supra note 3, at 20-21; GEE 136-38.

21. See notes $42-43$ supra and accompanying text.

22. See notes 60-62 infra and accompanying text.

23. National Sur. Corp. v. United States, 133 F. Supp. 381, 384 (Ct. Cl.), cert. denicd, 350 U.S. 902 (1955). The policy of Government protection is no longer applicable as the Government stands as a mere formal defendant with no attendant risk of loss. If fearful of multiple liability, it may readily exercise its rights of interpleader of the interested parties in any action that arises for payment. See Newark Ins. Co. v. United States, 169 F. Supp. 955 (Ct. Cl. 1959).

24. Recovery of retainages by general creditors is considered a windfall in the private field. Pacific Indem. Co. v. Grand Ave. State Bank, 223 F.2d 513, 521 (5th Cir. 1955). It is doubtful that general creditors take into account the substantive technical distinctions between public and private contracts before extending credit.

25. See In re Dutcher Constr. Corp., 197 F. Supp. 441, 443 (W.D.N.Y. 1961). 
clusively relied upon by the surety for mitigation of loss, ${ }^{26}$ denying him such rights must increase the loss and therefore the rate charged for the bond, which adds to the Government's cost for the prime contract. ${ }^{27}$ Such differential, moreover, may unduly restrict the underwriting activities of surety companies to the detriment of the capable, but small contractor, ${ }^{28}$ which would be

26. See BackMan 90-91; Haas, supra note 8 , at 212; CRIST 122-23. Considering the following loss experience table, the importance of salvage becomes apparent.

Surety Association of Anerica: Fidelity, Surety and Forgery Countrywide Classification: Association Companies:

\begin{tabular}{lll}
\hline Gross Dirct Premituns & Net Losses incl. & \\
Written less Cancella- & claim \& salvage & Loss \\
tions \& \& return premiums & expense & Ratio
\end{tabular}

Year 1960-Public \& Private Contracts, not including Federal:

$$
\$ 72,699,357
$$

Year 1960, Federal Contracts:

$$
\$ 12,911,266
$$

$\$ 12,195,196$

$94.5 \%$

Adding to the above loss ratios the ratio of expense of underwriting to earned premiums $-51.8 \%$ - the extent of loss, particularly on federal construction work, becomes apparent. BackMan 131. This loss experience seems to transform the surety company into an insurance company, a result directly contrary to the intended end of suretyship. See BackMan 130-50; Lunt, SuREty Bonds 5 (1922) [hereinafter cited as LUNT]; Crist 6-11; SURETY Association of America, op. cit. supra note 3, at 16-18, 29-31; Texas A.G.C. Chapters Executrve Councin, op. cit. supra note 5, at 10.

Theoretically, the surety company takes no risk whatever because the contractor, presumed to be financially able to assume the risks of construction, is still the primary obligor under the contract and bond. Smoot Sand \& Gravel Corp. v. Commissioner, 241 F.2d 197 (4th Cir. 1957), cert. dcnied, 354 U.S. 922, rehearing denied, 354 U.S. 943 (1958) ; LUNT 5; Crist 7; Backmain 34-35, 63. Indeed, the premium exacted is primarily intended as a service fee for the surety's loan of credit and the costs of underwriting. Unlike insurance, it is not consideration for the bond, and it is only secondarily retained as a pool for bond losses. Lunt 6; Backaran 34-35, 50; Mackall 10, 12-13; Crist 32-35, 172. For a comparison of suretyship and banking, see BACKMAN 204-08.

Yet, many courts persist in regarding a surety bond as a contract of insurance without regard to the former considerations. See, e.g., Massachusetts Bonding \& Ins. Co. v. J. R. Thompson Co., SS F.2d 825 (Sth Cir.), cert. denied, 301 U.S. 707 (1937); Commerce Title Guar. Co. v. United States, 32 F. Supp. 73 (W.D. Tenn. 1940), aff'd per curiam, 121 F.2d 452 (6th Cir. 1941), cert. denied, 314 U.S. 657 (1942); Standard Oil Co. v. Remer, 167 Minn. 352, 209 N.W. 315 (1926).

27. See In $r c$ Dutcher Constr. Co., 197 F. Supp. 441 (1961); note 26 supra.

28. The required contract bonds under the Miller Act serve primarily as screening devices which, by operation of the underwriting process, protect the Government and suppliers from the dangers of relying on irresponsible or incompetent contractors. Haas, supra note 8, at 207-08; Crist 27-28, 35; Texas A.G.C. Chapters Executrve Councis, op. cit. supra note 5, at 10-13. But see, SURETy Association of AMERICA, op. cit. supra note 3, at 9.

Since underwriting is largely a matter of judgment and the level of acceptable rate and risk may be determinative of surety success, surety companies scrutinize with great care 
directly contrary to the express governmental policy of encouraging the participation of small business in federal construction projects. ${ }^{20}$ These considerations, therefore, demonstrate the need for clearly establishing the subrogative rights of the Miller Act payment bond surety to retainages withheld under a public contract. Such rights must depend upon traditional and sound principles of subrogation that can be comprehended and uniformly applied by the courts.

Henningsen v. United States Fid. \& Guar. Co. ${ }^{30}$ was the earliest judicial attempt to provide a doctrinal foundation upon which to rest the rights of the payment bond surety to retainages held by the Government as stakeholder. In that case, an action by the surety to restrain payment to an assignee bank of the fund held by the Government subsequent to its contractor's performance, the Supreme Court held that the surety upon payment to suppliers had not only released the contractor from his obligations to such suppliers, but had also, to the same extent, released the Government from all "equitable obligations" to see that they were paid. ${ }^{31}$ The surety thereby became entitled to equitable rights in the fund which dated back to the commencement of its obligation-the date of the bond's execution. ${ }^{32}$ This statement of the surety's rights is susceptible of two constructions, both equally questionable under sound principles of suretyship. Either the Court was saying that the surety, as in the case of default of its principal (the contractor), has an action for simple reimbursement against the Government as a secondary principal; or it was saying that the Government, as equitable obligor, though not legally bound, may exercise its discretion in order to satisfy an obligation which it, in equity and good conscience, should satisfy. In either case, the Government,

the factors of good risk-the contractor's experience, ability, familiarity with the kind of work sought, financial status, cash position, equipment and general history. MACkALL 78; CRIST 7, 11; LUNT 5 . If the level of risk rises in federal contracts, the availability of surety coverage to the small contractor will necessarily be limited, although it is often the most solid contractor, not the small or jerry builder who defaults. CusHMAN, op. cit. supra note 1 , at 12-13; BACKMAN 30-31.

29. Small business concerns shall be afforded an equitable opportunity to compete for prime contracts and subcontracts.

41 U.S.C.A. App., Rules \& Regs. § 1-1.702(b) (1) (Supp. 1961).

30. 208 U.S. 404 (1908).

31. Id. at 410 . The Government's equitable obligation stems from the equitable notion that the Government should not retain the benefits of the work of laborers and materialmen whom the contractor should have paid, while at the same time paying the unrelated debts of the contractor. National Sur. Corp. v. United States, 133 F. Supp. 381, 384 (Ct. C1. 1955). See the statement of the Supreme Court of Missouri in St. Louis Public Schools v. Woods, 77 Mo. 197, 201-02 (1883):

I think the law is not inclined to deny the board, even if it is a municipal corporation, the satisfaction and ease of conscience which the private citizen is naturally supposed to experience, when he reflects that the structure he dwells in has been entirely paid for, from the mason who laid the foundation to the artist who frescoed the ceilings.

32. 208 U.S. at 411, quoting from Prairie State Bank v. United States, 164 U.S. 227 (1896) (Heard Act performance bond). 
like the contractor, is afforded surety coverage, and consequently becomes the "principal" of the surety; it is at the same time, however, unlike the contractor, the obligee (the beneficiary) of the bond. Traditional concepts of reimbursement and of subrogation, moreover, although broad enough to include every instance in which a surety pays the debt for which another is primarily liable, ${ }^{33}$ would not extend to the present case where the Government is merely an equitable obligor, at most secondarily responsible for expenses of labor and material incurred under its contracts. Despite these doctrinal difficulties, however, many courts in subsequent cases have accepted the Henningsen rationale without comment. ${ }^{34}$

But other courts, distressed by the absence of any legal obligation on the part of the Government to satisfy suppliers' claims, have experienced difficulty in applying Henningsen. ${ }^{35}$ Because the Government was fully satisfied upon completion of performance, such courts conclude that the designation of the Government as obligee of the payment bond must be merely a formal one provided for the convenience of claimants; this could not therefore establish a governmental right to use the retainages to which the surety could be subrogated. ${ }^{36}$ But a source of the surety's subrogative rights could still be found, they reasoned, since the "necessary effect" of Henningsen was that, "in spite of or in addition to the giving of the bond," the laborers and materialmen had "an original and continuing equitable priority in the fund" which could be transferred to the surety. ${ }^{37}$ Some courts characterized this right of suppliers as an "equitable lien" on the fund..$^{38}$ However described, courts adopting this

33. Home Owners' Loan Corp. v. Sears, Roebuck \& Co., 123 Conn. 232, 237, 193 Ati. 769, 772 (1937) (subrogation). See Simpson, SuRETYSHIP 229-30 (1950) (reimbursement).

34. The "equitable righ" in Henringsen has been considered synonymous and interchangeable with the term "equitable lien." Danais v. DeMatteo Constr. Co., 102 F. Supp. 874, 877 (D.N.H. 1952). Courts have also variously termed the obligation of the Government a "moral obligation," American Sur. Co. v. Westinghouse Elec. Mfg. Co., 75 F.2d 377, 379 (5th Cir. 1935), aff'd, 296 U.S. 133 (1935) ; Belknap Hardware \& Mfg. Co. v. Ohio River Contract Co., 271 Fed. 144 (6th Cir. 1921) ; or an "equitable obligation," California Bank v. United States Fid. \& Guar. Co., 129 F.2d 751 (9th Cir. 1942) ; Morgenthau v. Fidelity \& Deposit Co., 94 F.2d 632, 635 (D.C. Cir. 1937). On the origin and development of the doctrine of the "equitable lien" acquired by subrogation to the rights of the United States, see Note, 20 U. CINc. L. REv. 494, 499-500 (1951).

35. The source of difficulty was the seeming dependence of Hemingsen on Prairie State Bank v. United States, 164 U.S. 227 (1896). In that case, the Supreme Court awarded the retainages to a Heard Act performance bond surety on the basis of subrogation to the rights of its obligee, the United States. These courts found it difficult to make the conceptual plunge from performance bond principles into the payment bond field.

36. E.g., Belknap Hardware \& Mfg. Co. v. Ohio River Contract Co., 271 Fed. 144 (6th Cir. 1921).

37. Id. at 149. See American Sur. Co. v. Westinghouse Elec. Mfg. Co., 75 F.2d 377 (5th Cir.), aff'd, 296 U.S. 133 (1935) ; Royal Indem. Co. v. United States, 93 F. Supp. 891 (Ct. Cl. 1950).

38. E.g., Martin v. National Sur. Co., 300 U.S. 588 (1937) ; United States Fid. \& Guar. Co. v. Sweeney, 80 F.2d 235 (8th Cir. 1935) ; Philadelphia Nat'l Bank v. McKinlay, 
approach hold that the surety has the right, which exists potentially from the moment of execution of the bond, to be subrogated to these equities, ${ }^{39}$ a right which, upon payment following the contractor's default, relates back to the date of execution of the bond, ${ }^{* 0}$ thus creating secured rights in the fund superior to those of the contractor's trustee in bankruptcy. ${ }^{41}$

This subrogative route of the surety through the rights of laborers and materialmen to recovery of the fund has been rejected in some jurisdictions on the same ground on which the Government interest as a basis for the surety's derivative rights was repudiated. The absence of the Government's legal obligation and its immunity from liens on its property implied that the gratuitous bond protection afforded laborers and materialmen by Congress constituted the sole and exclusive remedy and measure of their rights. ${ }^{42}$ Further, the additional protection granted by recognition of equitable rights of the suppliers in the fund was presumed to be unnecessary and inconsistent with the very existence of the payment bond which supposedly provided full protection. ${ }^{43}$ But in some cases, as where the surety as well as the contractor was bankrupt ${ }^{44}$ or where the surety had paid claims up to the penal sum of the bond leaving some

72 F.2d 89 (D.C. Cir. 1934), cert. denied, 293 U.S. 583 (1934); In re P. McGarry \& Son, 240 Fed. 400 (7th Cir. 1917).

For a state bond case in accord, see In re Heintzelman Constr. Co., 34 F. Supp. 109 (W.D.N.Y. 1940); but see In re H. A. Moore Co., 31 F.2d 321 (M.D. Pa. 1929).

39. See American Fid. Co. v. National City Bank, 266 F.2d 910, 914 (D.C. Cir. 1959).

40. American Fid. Co. v. National City Bank, supra note 39; United States Fid. \& Guar. Co. v. Sweeney, 80 F.2d 235 (8th Cir. 1935) ; National Sur. Co. v. United States, 133 F. Supp. 381 (Ct. Cl. 1955).

For state bond cases in accord, see Street v. Pacific Indem. Co., 79 F.2d 68 (9th Cir.), cert. denied, 297 U.S. 718 (1935) ; Seaboard Sur. Co. v. North Dakota, 94 F. Supp. 177 (D.N.D. 1950) ; United States Fid. \& Guar. Co. v. John R. Alley \& Co., 34 F. Supp. 604 (W.D. Okla. 1940).

41. E.g., In re P. McGarry \& Son, 240 Fed. 400 (7th Cir. 1917). For state bond cases in accord, see United States Fid. \& Guar. Co. v. John R. Alley \& Co., supra note 40; Street v. Pacific Indem. Co., stipra note 40.

Concerning the superior claim of laborers and materialmen in bankruptcy, see Kreimer v. Second Fed. Sav. \& Loan Ass'n, 196 Pa. Super. 644, 176 A.2d 132 (1961) ; In re Heintzelman Constr. Co., 34 F. Supp. 109 (W.D.N.Y. 1940); but see In re L. H. Duncan \& Sons, 46 F. Supp. 825 (W.D. Pa. 1941).

42. Phoenix Indem. Co. v. Earle, 218 F.2d 645, 649 (9th Cir. 1955); In rc Flotation Systems, 65 F. Supp. 698, 701-02 (S.D. Cal. 1946).

43. In re Flotation Systems, stipra note 42, at 702:

No principle warrants our creating an equitable lien in their favor as against general creditors who do not have the additional protection of the bond.

Indeed, such courts note that the very purpose of the Miller Act payment bond was to shift the ultimate risk of loss from workmen and suppliers to the surety. American Sur. Co. v. Hinds, 260 F.2d 366, 368 (10th Cir. 1958).

44. E.g., Martin v. National Sur. Co., 300 U.S. 588 (1937) ; Philadelphia Nat'l Bank v. McKinlay, 72 F.2d 89 (D.C. Cir.), cert. denied, 293 U.S. 583 (1934); Hadden v. United States, 132 Ct. Cl. 529 (1955). The Supreme Court in United States v. Munsey Trust Co., 332 U.S. 234, 242 (1947), expressly reserved decision on this situation. 
claimants unpaid, ${ }^{45}$ courts have recognized that the bond is inadequate protection and have allowed these claimants access to the fund, which suggests that suppliers clearly have rights other than those afforded by the bond. Such additional rights, moreover, need not be considered inconsistent with the existence of the bond, since the statutory bond does not necessarily discharge all the underlying equities, the recognition of which forms the basis of the enactment of the Miller Act. ${ }^{46}$ Indeed, such legislation has been construed as a "precursor of judicial recognition of an enforceable equitable right of unpaid furnishers of labor or materials" to funds held by the Government subsequent to completion of construction. ${ }^{47}$ In any case, the statutory bond enactment need not imply any legislative policy decision as to the respective rights of the surety and third parties; on the contrary, absent any indication of preference, the presumption would seem in favor of providing the surety with rights to the fund in the public field analogous to those established through commercial law principles applicable to private contracts. ${ }^{48}$

The confusion in this area was heightened by sundry interpretations of the Supreme Court's decision in United States v. Munsey Trust Co. ${ }^{49}$ The Court, reversing the holding of the Court of Claims which awarded the retainages to a receiver for the benefit of a surety who had paid laborers and materialmen, firmly established the principle that the Government, possessing withheld funds, is the best secured of all creditors and may apply such moneys in "set-off" against any debts, from whatever source, owed it by the contractor. ${ }^{50}$ But this

45. E.g., American Sur. Co. v. Westinghouse Elec. Mfg. Co., 296 U.S. 133 (1935). Even where the suppliers went unpaid because of their own failure to bring an action against the surety within the statutory period, the surety is not entitled to share in the assets of the bankrupt's estate until all members of the class covered by the bonds are paid. American Sur. Co. v. Sampsell, 327 U.S. 269 (1946). See Simrpson, Suretyship 213-14 (1950).

46. Recognizing the existence of equitable rights of laborers and materialmen to be paid, the provision of a bond merely constitutes a vehicle for the securing of such rights. For example, the rights of laborers and materialmen in the private field continue to exist regardless of the bond, each supplementing the other. See notes 1-5 supra and accompanying text; Martin v. National Sur. Co., 85 F.2d 135 (Sth Cir. 1936); American Sur. Co. v. Westinghouse Elec. Mfg. Co., 75 F.2d 377, 379 (5th Cir.), aff'd, 296 U.S. 133 (1935); Belknap Hardware \& Mfg. Co. v. Ohio River Contract Co., 271 Fed. 144, 149 (6th Cir. 1921).

47. American Sur. Co. v. Westinghouse Elec. Mfg. Co., 75 F.2d 377, 379 (5th Cir.), aff'd, 296 U.S. 133 (1935).

48. Concerning the feeling of some courts, notably the Court of Claims, that the rules of private commercial law should be maintained under federal contracts, see NATIONAL Law Center of George Washington Univ., Summary of Proceedings: Conference on United States Governament Construction Contracts, Nov. 6 \& 7, 1961, at p. 39 (reference was made to the Assignment of Claims Act and the absence of congressional intent to change the rules of private commercial law).

49. 332 U.S. 234 (1947).

50. Id. at 239, where the Court said, quoting Gratiot v. United States, 40 U.S. (15 Pet.) 336,370 (1841) :

The government has the same right "which belongs to every creditor, to apply the 
"set-off" situation must be distinguished from cases where the Government is a mere "stakeholder," for in the latter no claim is lodged against the United States ${ }^{51}$ and the subrogation-destroying-superior-equity which the Government asserts in the former is not present. ${ }^{22}$ Thus, it is essential to a proper construction of the Munsey opinion to recognize its peculiar application to cases in which the surety is in actual conflict with the direct interests of the Government as a creditor in its own right. ${ }^{53}$

The Court of Appeals for the Tenth Circuit in American Sur. Co. v. Hinds, ${ }^{04}$ where a Miller Act payment bond surety was denied any subrogative rights to retained funds which had been disbursed to the defaulting contractor's trustee in bankruptcy, failed to appreciate this distinction. ${ }^{5.5}$ Following language in Munsey, the court observed that since laborers and materialmen have no enforceable rights against the Government, the surety derived no advantage by subrogation to their rights. ${ }^{56}$ But the fact that suppliers have no legally en-

unappropriated moneys of his debtor, in his hands, in extinguishment of the debts due to him."

51. See note 23 supra and accompanying text. The apparent concern of the Court in Munsey was that the underwriter of a bond, which the United States had gratuitously provided for the protection of laborers and materialmen, was asserting rights arising under the bond to the detriment of the United States. The Court felt that this would allow the surety to increase the risks of the Government and concluded that such a result could not be permitted. 332 U.S. at 244.

An earlier example of this attitude can be found in Lawrence v. United States, 71 Fed. 228, 230 (D.S.C. 1896):

[T] hese laborers and material men have no rights, as against the government,rights which can be enforced. . . . They are recipients of its bounty, debtors to its good will, objects of its provident care, in whose favor ... it exercises its right and privilege to withhold the money until their claims are satisfied. Nor have they any specific interest in the money so withheld.

52. The usual concept of subrogation requires an absence of outstanding and superior equities, upon which the substitution of a subrogee into the shoes of its creditor is conditioned. See Home Owners' Loan Corp. v. Sears, Roebuck \& Co., 123 Conn. 232, 238-40, 193 Atl. 769, 772 (1937). Where, as in Muthsey, the Government is asserting a right of set-off against claims which ultimately are founded on its recognition of equitable rights, the condition of subrogation is not present.

53. The Munsey Court itself stated that:

[W] e have recognized the peculiarly equitable claim of those responsible for the physical completion of building contracts to be paid from available moneys ahead of others whose claims come from the advance of money. But in all those cases, the owner was a mere stakeholder and had no rights of its own to assert.

332 U.S. at 240 (emphasis added). See Royal Indem. Co. v. United States, 93 F. Supp. 891 (Ct. Cl. 1950), as to the distinguishability of Mutnsey and other cases from "stakeholder" suits.

54. 260 F.2d 366 (10th Cir. 1958).

55. Id. at 368 .

56. Ibid. See Bowden v. United States, 239 F.2d 572 (9th Cir. 1956), cert. denied, 353 U.S. 957 (1957) ; Bank of Arizona v. National Sur. Corp., 237 F.2d 90 (9th Cir. 1956); Phoenix Idem. Co. v. Earle, 218 F.2d 645 (9th Cir. 1955).

For state bond cases in accord, see City of Philadelphia v. National Sur. Corp., 140 
forceable rights against the Government for their compensation is pertinent only where the Government is itself claiming the fund, for, in that case, the concept of equitable rights, discretionarily derived from the Government, is meaningless; it does not, however, argue against the presence of equitable rights in the absence of the Government's claim. The opinion in Munsey, nevertheless, seemed to suggest that even in the latter case suppliers would have no claim. In an unusual display of paralogism, Mr. Justice Jackson observed that, even if it be posited that suppliers had an equitable lien on the fund and that the Government would therefore be justified in refusing to disburse the fund to the contractor, they could not have a lien upon moneys which the United States might "legally keep," for laborers and materialmen may not claim moneys not due the contractor. ${ }^{57}$ But the Government may "legally keep" the fund because of the equitable lien of suppliers. This argument, moreover, assumes that the suppliers' sole claim is through the rights of the contractor which, in addition to being contrary to the weight of previous authority, ${ }^{58}$ begs the very question at issue. 59

Quoting at length from Munsey, the Hinds court denied the existence of any equitable lien of laborers and materialmen on the fund to which the surety might be subrogated on the further ground that, "more likely," the only motive of the Government for retaining the percentages was to secure timely performance, rather than to assure the payment of laborers and materialmen. ${ }^{60}$ Were this the case, the fund would be unconditionally payable upon satisfac-

F.2d 805 (3d Cir. 1944) ; State Bank v. Dan-Bar Contracting Co., 12 App. Div. 2d 416, 212 N.Y.S.2d 386 (1961); Farmers State Bank v. Burns, 212 Minn. 455, 4 N.W.2d 330 (1942). Cf. In re L. H. Duncan \& Sons, 46 F. Supp. 825 (W.D. Pa. 1941), where the surety was allowed priority to wage claims, but not to material claims, under Pennsylvania law.

57. 332 U.S. at $241-42$.

58. See notes $32,34,37, \& 38$ supra and accompanying text.

59. See Note, 20 U. Cinc. L. REv. 494, 498 (1951). The Court noted that, in any event, the surety has paid laborers and materialmen and the Government is therefore free to disburse the fund unconditionally since the equities of the suppliers have been discharged. The surety, in order to rely on these rights, must establish that such rights existed before payment of suppliers' claims. 332 U.S. at 242.

If before they are paid, the fund to which they are said to be entitled to look is unavailable for the very reason that they are unpaid, the surety relies on nothing when it relies on those nonexistent "rights."

Ibid. This statement in Munsey on subrogation and the manner in which it arises would, if followed, negative subrogation in all cases, since, as the Court itself noted, the substitution which subrogation contemplates places the subrogee in the position of the creditor paid as if the debt had not been paid. Ibid. See Lumpkin v. Mills, 4 Ga. 343, 345, 348-49 (1848); cf. Patton's Executor v. Smith, $130 \mathrm{Ky} .819,114$ S.W. 315 (1908).

60. 260 F.2d at 368, quoting United States v. Munsey Trust Co., 332 U.S. 234, 243 (1947) :

[A] lthough we have assumed ... that assurance that laborers and materialmen will be paid is one of the reasons for retaining the money, it seems more likely that completion of the work is the only motive. ... It is hardly reasonable to withhold 
tory completion, title would vest in the trustee, ${ }^{\mathbf{6 1}}$ and the laborers and materialmen could have no equitable lien on the fund. ${ }^{62}$ Such language in Munsey, however, was intended to preclude the possibility of the surety asserting a claim superior to the Government's claim of set-off, for, were the Government legally obligated to retain the fund as security for the payment of laborers and materialmen, diversion of the fund by the Government, the obligee, would violate the rule that an obligee, as against a surety, may not apply security in satisfaction of a debt other than the one it secured. ${ }^{63}$ But the lack of legal obligation to withhold the fund for the benefit of laborers and materialmen does not negative the possibility that the Government might have discretionary authority to retain the moneys for this purpose. In fact, where a surety has satisfied the claims of suppliers, many courts have held that the funds are not unconditionally payable to the contractor upon satisfactory performance. ${ }^{04}$ The standard federal construction contract itself implies the existence of such dis-

money in order to assure payments which perhaps can be made only from the moneys earned.

See also Schmoll v. United States, 63 F. Supp. 753 (Ct. Cl.), cert. denied, 329 U.S. 724 (1946) ; Farmers State Bank v. Burns, 212 Minn. 455, 4 N.W.2d 330, 334 (1942). Yet in the private field, the existence of the above practical consideration does not preclude retention subsequent to completion. See GEE 150-51.

61. Bankruptcy Act $\S 70 a(6)$ (1959), 53 Stat. 880 (1938), 11 U.S.C. \& 110a(6) (1958).

62. See Schmoll v. United States, 63 F. Supp. 753 (Ct. Cl.), cert. denied, 329 U.S. 724 (1946). Minsey suggested that the contractor might compel payment of the fund upon satisfactory completion. 332 U.S. at $241 \mathrm{n} .4$. It is true that under the standard federal construction contract, the amount due the contractor becomes payable upon completion and acceptance of all work, and, if required, after the contractor has furnished the Government with a release of all claims against the Government arising under and by virtue of the contract, other than such claims as may be specifically excepted from operation of the release. Standard Form No. 23, 41 U.S.C. App., Rules \& Regs. \$ 54.13, Art. 16(d) (1958), and Standard Form No. 23A, Art. 7(e), 26 Fed. Reg. 1050 (1961). These discretionary payment provisions do give the contracting officer great leeway, even in the face of outstanding claims against the contractor and the United States.

For state bond cases considering the fund unconditionally payable, see State Bank v. Dan-Bar Contracting Co., 23 Misc. 2d 487, 199 N.Y.S.2d 309 (Sup. Ct. 1960), aff'd, 12 App. Div. 2d 416, 212 N.Y.S.2d 386 (1961).

63. 332 U.S. at 243 and cases cited therein. One court, apparently ignoring this rule and basing its decision on the dictum of Munsey, considered the Government's right of setoff superior to the claim of a surety completing performance under obligation of a Miller Act performance bond. Standard Acc. Ins. Co. v. United States, 97 F. Supp. $\$ 29$ (Ct. Cl. 1951). Such reasoning is clearly erroneous in light of (1) the express declaration of MLunsey granting the surety superiority where there exists a sound basis of subrogation, (2) the accepted principle of equitable subrogation to the rights of the Government where the surety has benefited the Government by assuming the contractor's duty to pay damages, Prairie State Bank v. United States, 164 U.S. 227 (1896); Hardin County Sav. Bank v. United States, 65 F. Supp. 1017 (Ct. Cl. 1946), and (3) Munsey's explicit recognition of the rule regarding diversion of security, 332 U.S. at 243.

64. The lien has been afforded to the payment bond surety where the contract explicitly provided for such retention, Standard Acc. Ins. Co. v. Federal Nat'1 Bank, 112 F.2d 692 (10th Cir. 1940) (state bond); In re Cummins Constr. Corp., 81 F. Supp. 193 (D. Mdd. 
cretionary power. ${ }^{65}$ And, notwithstanding dictum in Munsey to the contrary, ${ }^{66}$ it is clear that the Government, in practice, does not consider the fund unconditionally payable. ${ }^{67}$

1948); where the contract was silent as to the purpose of the retainages, National Sur. Corp. v. United States, 133 F. Supp. 381, 384 (Ct. Cl. 1955) ; and where the Government was legally bound only to retain the fund until performance, California Bank v. United States Fid. \& Guar. Co., 129 F.2d 751 (9th Cir. 1942). The fund might be considered out of reach of the contractor-principal on a number of grounds that have arisen in the private and public-state and federal-construction contract cases: (1) The contractor has no property interest in the fund until payment of suppliers. Fidelity \& Deposit Co. v. New York Housing Authority, 241 F.2d 142 (2d Cir. 1957) (no conditional right to the fund under state law which controls); Philadelphia Nat'l Bank v. McKinlay, 72 F.2d 89 (D.C. Cir. 1934) (bankrupt has no title) ; United States Fid. \& Guar. Co. v. Triborough Bridge Authority, 297 N.Y. 31, 74 N.E.2d 226 (1947) (state bond). (2) The contractor's failure to comply with the contractual duty to pay laborers and materialmen, not justified by the conduct of the owner, discharges the latter's duty to give the contractor the withheld funds. Atlantic Ref. Co. v. Continental Cas. Co., 183 F. Supp. 478 (W.D. Pa. 1960) (private contract) ; Steeleraft Mfg. Co. v. Hewkin, 148 F. Supp. 872 (E.D. Ill. 1956) ; United States Fid. \& Guar. Co. v. Miller, 143 F. Supp. 941 (W.D.N.C. 1956). (3) The equitable lien of the surety on the fund is an encumbrance which the principal cannot avoid, Philadelphia Nat'l Bank v. McKkinlay, supra, nor can the Government decide the merits of competing claims by delivering the stake to one. Newark Ins. Co. v. United States, 169 F. Supp. 955 (Ct. Cl. 1959).

65. Standard Form No. 23, 41 U.S.C. App., Rules \& Regs. § 54.13, Art. 16(b) (1958), the standard federal construction contract, provides for retention of ten percent of all monthly partial payments made during the progress of work subject to any later modifications authorized under Art. 16(b). Upon satisfactory completion the retainage and any unpaid contract balance becomes due and payable under Art. 16(d). However, upon presentation of the properly executed and certified voucher of completion, the Government may require the contractor to furnish a release of all claims against the Government arising under the contract, thus providing one source of authority for maintaining possession of the fund subsequent to completion. Standard Form No. 23, 41 U.S.C. App., Rules \& Regs. \$ 54.13, Art. 16(d) (1958), and Standard Form No. 23A, Art. 7(e), 26 Fed. Reg. 1050 (1961). In addition, 41 U.S.C. $\$ 54.13$, Art. 17(a) (App. 1958), provides that the contracting officer may withhold accrued payments to the extent necessary to ensure payment to laborers and mechanics of the difference between the rate of wages required by contract and the rate of wages actually received by them. Though the provision literally authorizes such only where the rate of pay has been lowered below the specified minimum federal standard, a prudent disbursing officer presumably would be empowered to protect workmen from the greater included "offense"-nompayment. It should be noted that the new contract form, effective July 1, 1961, is totally silent as to the above. See Standard Form No. 23A, 26 Fed. Reg. 1050 (1961). See Note, 20 U. Cinc. L. REv. 494, 495 (1951); Speidel, "Stakeholder" Payments Under Federal Construction Contracts: Payment Bond Strcty vs. Assignee, 47 VA. L. Rev. 640, $643 \mathrm{n} .12$ (1961), as to the authority of the disbursing officer to maintain control of withheld funds subsequent to completion.

66. 332 U.S. at 241 n.4.

67. The Government, when unable to obtain a release of labor and material claims from the contractor, can exercise its discretion under Articles 16(d) and 17(a) of the contract, supra note 65. Or where it has been put on notice of various claims, the Government usually will not attempt to decide the merits of the claims or put itself in jeopardy of multiple losses, but will interplead the interested parties when appropriate. See Newark Ins. Co. v. United States, 169 F. Supp. 955 (Ct. Cl. 1959) ; Continental Cas. Co. v. United 
On the basis of the mistaken assumption that the fund is unconditionally payable, the Hinds court summarily denied any subrogative right of the surety to the fund through the Government. ${ }^{68}$ In so doing, the court noted some recent indistinguishable cases which implicitly recognized such authority and which were contrary to its holding, ${ }^{69}$ but denied the validity of such cases because of their reliance on earlier ones in which the competing claimants were assignee banks. This situation, the court believed, was distinguishable from the present case, where the claimant was the contractor's trustee in bankruptcy. ${ }^{70}$ But it is clear that the surety's rights to the retainages, as determined by principles of subrogation, are not dependent upon the identity of the third party claimant. ${ }^{71}$ If the trustee could utilize his statutory powers of avoidance in the face of the surety's subrogative rights, he would be entitled to the witheld funds. But the trustee's statutory powers do not deny the existence of subrogative rights, but only may potentially avoid such rights that are, in fact, established. Since the equitable lien or priority of the surety "relates-back" to the date of the bond as a matter of law, ${ }^{72}$ however, these liens, constituting charges or encumberances on property, ${ }^{73}$ will be valid in all cases where bankruptcy has ensued four or more months subsequent to execution of the bond 74

States, 169 F. Supp. 945, 946 (Ct. Cl. 1959). Similarly, when it has a claim of its own to set-off, the United States must hold "the unappropriated moneys of his debtor in his hands," necessitating retention of the fund subsequent to acceptance of the work. United States v. Munsey Trust Co., 332 U.S. 234, 239 (1947), quoting from Gratiot v. United States, 40 U.S. (15 Pet.) 336, 370 (1841).

68. 260 F.2d at 368 .

69. Ibid. The cases contra are, e.g., National Sur. Corp. v. United States, 133 F. Supp. 381 (Ct. Cl. 1955) ; Royal Indem. Co. v. United States, 93 F. Supp. 891 (Ct. Cl. 1950); In re Cummins Constr. Corp., 81 F. Supp. 193 (D. Md. 1948); United States Fid. \& Guar. Co. v. Triborough Bridge Authority, 297 N.Y. 31, 74 N.E.2d 226 (1947).

70. 260 F.2d at 368 .

71. Cf. In re Scofield Co., 215 Fed. 45 (2d Cir. 1914).

72. See Gray v. Travelers Indem. Co., 280 F.2d 549, 552 (9th Cir. 1960); United States Fid. \& Guar. Co. v. United States, 201 F.2d 118, 121 (10th Cir. 1952); Glenn v. American Sur. Co., 160 F.2d 977, 982 (6th Cir. 1947) ; Alabama-Tennessee Natural Gas Co. v. Lehman-Hoge \& Scott, 122 F. Supp. 314, 319 (N.D. Ala. 1954); American Fid. Co. v. Delaney, 114 F. Supp. 702, 710 (D. Vt. 1953) ; In re Van Winkle, 49 F. Supp. 711, 712-13 (W.D. Ky. 1943).

Several cases suggest that the equitable lien thus acquired is independent of and consistent with rights under the assignment or under any form of subrogation. See, e.g., Colusa-Glenn Prod. Credit Ass'n v. Phoenix Ins. Co., 145 F. Supp. 844 (N.D. Cal. 1956); Alabama-Tennessee Natural Gas Co. v. Lehman-Hoge \& Scott, supra at 318-19.

73. E.g., Tobin v. Insurance Agency Co., 80 F.2d 241, 243 (8th Cir. 1935).

74. Even where the lien is deemed to arise within four months of bankruptcy, it may still serve to prevent an unjustified "windfall" to general creditors who never had any interest in the contract funds without constituting a preference. Pacific Indem. Co. v. Grand Ave. State Bank, 223 F.2d 513 (5th Cir. 1955), noted with approval in 34 TEx. L. Rev. 758 (1956).

Further, the Bankruptcy Act, $\S 60$ (a) (6), 64 Stat. 25 (1950), 11 U.S.C. § 96(a) (6) (1958), does not declare the policy of the Act to be against the recognition of all equitable liens, but only against those "where available means of perfecting legal liens have not been 
and will thus entitle the surety to priority in payment from the fund over general creditors, ${ }^{75}$ subsequent lienholders, ${ }^{76}$ and the trustee in bankruptcy, ${ }^{77}$ notwithstanding his powers of avoidance.

Arguably, the Hinds court may have ignored the possibility of the surety having subrogative rights through the United States because of the subrogation provision of the Bankruptcy Act ${ }^{78}$ which seems to limit subrogative rights of the surety to those of the creditor paid-the laborers and materialmen. ${ }^{79}$ But, under settled principles of the law of bankruptcy, where the creditor has been paid in full before adjudication, the surety may elect to assert a claim in its own right, ${ }^{80}$ which claim has its source in the equitable lien derived from the Government's authority to withhold funds for the surety's benefit.

The court in Hinds might have attempted to distinguish the situation before it from those, as in Henningsen, where the Government continued to act as "stakeholder," on the ground that in this case the Government, by disburse-

employed." Danais v. M. De Matteo Constr. Co., 102 F. Supp. 874 (D.N.H. 1952), read with approval in Comment, 50 Nw. U.L. Rev. 541 (1955) ; Note, 17 U. PITT. L. Rev. 712 (1956). The whole of subsection (6) of the Act has application only where a legal lien can be acquired through court action. $102 \mathrm{~F}$. Supp. at 877. See also Cumberland Portland Cement Co. v. RFC., 140 F. Supp. 739, 753 (E.D. Tenn. 1953). Under this section, the equitable lien will not be recognized and will constitute a preference only if all other elements of a preference are present and if it is not perfected. Porter v. Searle, 228 F.2d 748 (10th Cir. 1955). See Weintraub \& Levin, The Equitable Lien, 30 REF. J. 92 (1956). Since there exists no method by which the lien may be perfected while the fund is in the hands of a "stakeholder," Cumberland Portland Cement Co. v. RFC., supra; Pacific Indem. Co. v. Grand Ave. State Bank, supra ; Danais v. M. De Matteo Constr. Co., supra, and creditors may have actual or constructive knowledge of the surety's rights, e.g., National Sur. Corp. v. United States, 133 F. Supp. 381 (Ct. Cl. 1955) ; Royal Indem. Co. v. United States, 93 F. Supp. 891, 894 (Ct. Cl. 1950), many courts have excluded the equitable lien of the surety from operation of the preference provision of the Act.

75. E.g., Massachusetts Bonding \& Ins. Co. v. New York, 259 F.2d 33 (2d Cir. 1958); London \& Lancashire Indem. Co. v. Endres, 290 Fed. 98 (8th Cir. 1923) ; Cox v. New England Equit. Ins. Co., 247 Fed. 955 (8th Cir. 1917) ; Cumberland Portland Cement Co. v. RFC, 140 F. Supp. 739, 754 (E.D. Tenn. 1953).

76. Royal Indem. Co. v. Board of Educ., 137 F. Supp. 890, 892 (M.D.N.C. 1956).

77. E.g., Philadelphia Nat'l Bank v. McKinlay, 72 F.2d 89 (D.C. Cir.), cert. denied, 293 U.S. 583 (1934); In re Cummins Constr. Corp., 81 F. Supp. 193 (D. Md. 1948).

78. Bankruptcy Act § 57(i), 52 Stat. 866 (1938), 11 U.S.C. § 93(i) (1958).

79. The Bankruptcy Act provides that a surety, upon proving the claim of the creditor against the bankrupt estate and showing that he has secured the debt, may be subrogated to the extent of the creditor's rights whether the surety paid the creditor before or after adjudication in bankruptcy. Bankruptcy Act $\$ 57$ (i), 52 Stat. 866 (1938), 11 U.S.C. § 93(i) (1958). See also Fidelity \& Deposit Co. v. Fitzgerald, 272 F.2d 121 (10th Cir. 1959), cert. denicd, 362 U.S. 919 (1960) ; Allen v. See, 196 F.2d 608 (10th Cir. 1952).

The Hinds court, citing with approval Phoenix Indem. Co. v. Earle, 218 F.2d 645 (9th Cir. 1955), may have adopted the latter's construction of $\$ 57$ (i), limiting the surety to the position of the laborers and materiaimen paid, and thereby, under both the Earle and Hinds interpretations of Munsey, relegated the surety to the status of a general creditor. See also City of Philadelphia v. National Sur. Corp., 140 F.2d 805 (3d Cir. 1944), limiting the surety's subrogative rights to those of materialmen, under Pennsylvania law.

80. See MacLachlan, BankRuptcy $§ 145$, at 138 (1956). 
ment of the fund, had chosen not to meet its "equitable obligation," nor to exercise its discretionary rights to withhold the fund, and had therefore erased any equities which the surety might otherwise assert through the Government. ${ }^{81}$ But if the surety from whatever source is possessed of an equitable lien on the fund, the prevailing view is that the Government, by unilateral action, cannot discharge these equities to the detriment of the lienholder. ${ }^{82}$ The surety's lien, not resting on the actual exercise of the Government's discretion but rather on its mere potential right to withhold such funds, is impressed upon the fund and is defeasible only upon payment of it to a bona fide creditor of the contractor taking without notice of the surety's rights. ${ }^{\mathrm{s}}$ Consequently, though the surety's strongest claim may be proffered where the Government has continued to be a "stakeholder," determinative of the surety's rights.

81. See American Fid. Co. v. National City Bank, 266 F.2d 910 (D.C. Cir. 1959); Bank of Arizona v. National Sur. Corp., 237 F.2d 90 (9th Cir. 1956) ; Cox v. New England Equit. Ins. Co., 247 Fed. 955 (8th Cir. 1917).

82. E.g., In re P. McGarry \& Son, 240 Fed. 400 (7th Cir. 1917). Recently, the Court of Claims, in Newark Ins. Co. v. United States, 169 F. Supp. 955 (Ct. Cl. 1959), held that a stakeholder (the United States) as between two competing claimants could not in effect decide the merits of their claims by delivery of the stake to one of them.

If it is made to appear that the Government's officials, after due notice of facts giving rise to an equitable right in the plaintiff surety company, and of the plaintiff's assertion of such a right, paid out ... the money in question to someone other than the plaintiff, the plaintiff will be entitled to a judgment.

$I d$. at 957 . The award was made to the surety, even though there was no stake and the Government was out of pocket.

83. When the surety assumed the obligations of suretyship,

its equity at once commenced with its obligation to see that ... [the contractor] performed all the obligations which the contract with the government imposed upon it, including its obligations to promptly pay the laborers and materialmen.

In re Scofield Co., 215 Fed. 45, 50 (2d Cir. 1914). It effects a continuing priority to payment from the fund. Belknap Hardware Mfg. Co. v. Ohio River Contract Co., 271 Fed. 144, 148-49 (6th $\mathrm{Cir}$. 1921). Thus where the fund is in the hands of the trustee in bankruptcy, who is vested with title to all property of the bankrupt as of the date of adjudication, e.g., American Sur. Co. v. Owens, 66 F.2d 190 (D.C. Cir. 1933) ; Philadelphia Nat'l Bank v. McKinlay, 72 F.2d 89 (D.C. Cir. 1934); Bankruptcy Act $\S 70$ e, 52 Stat. 880 (1938), 11 U.S.C. $\$ 110 \mathrm{a}$, the fund stands charged with the same equities the surety possessed when the fund was undistributed in the hands of the United States. United States v. Fogerty, 164 F.2d 26 (8th Cir. 1947) ; United States Fid. \& Guar. Co. v. Sweeney, 80 F.2d 235 (8th Cir. 1935) ; In re P. McGarry \& Sons, supra note 82.

Similarly, if the fund is disbursed to an assignee bank, it is impressed with the surety's equities. E.g., Aetna Cas. \& Sur. Co. v. Eastern Trust \& Banking Co., $156 \mathrm{Me}$. 87, 161 A.2d 843 (1960); Prairie State Bank v. United States, 164 U.S. 227 (1896).

However, the fund sought by the surety must be traceable to the disbursed retainages. Massachusetts Bonding \& Ins. Co. v. New York, 259 F.2d 33 (2d Cir. 1958) ("clearly traceable"); United States Fid. \& Guar. Co. v. Sweeney, supra; In re Supreme Appliance \& Heating Co., 113 F. Supp. 228 (W.D. Ky. 1953).

84. In the status of the Government, the surety might assume the retainages withheld under the contract, Standard Form No. 23, 41 U.S.C. App., Rules \& Regs. § 54.13, Arts. 
The inadequacies of the Hinds approach were recognized in In re Dutcher Constr. Corp., ${ }^{85}$ a case factually indistinguishable from Hinds, in which the district court relied on Henningsen to hold in favor of the surety's claim to "stakeholder" funds in the hands of the trustee in bankruptcy. ${ }^{86}$ But even the Dutcher court felt constrained to examine and distinguish the confusing anal$y$ sis of rights and obligations in Munsey. ${ }^{87}$ Indeed, it is not at all clear whether this court found for the surety on the basis of its subrogation to the equitable rights of laborers and materialmen in the fund or on the basis of the surety's satisfaction of the "equitable obligation" owed by the Government to assure payment of suppliers. But the foregoing analysis indicates that a failure to carefully distinguish the source of the surety's rights to the fund can have unfortunate results. Denying the existence of an "equitable lien" of laborers and materialmen on the fund, an equitable right which may appear to be the correlative of the Henningsen "equitable obligation," can cause a court, as in Hinds, to assume that the absence of rights derived from laborers and materialmen precludes the existence of any other subrogative rights of the surety. ${ }^{88}$ And considering the confused mixture of principles of both reimbursement and subrogation present in the Henningsen theory, it is not surprising that the surety's right to the fund through the Government has also been often denied.

Many of the conceptual difficulties raised by the use of the "equitable lien""equitable obligation" doctrines are avoided in Continental Cas. Co. v. United States. ${ }^{80}$ In that case, as in Henningsen, the United States had maintained possession of the retainages and unpaid contract balance as "stakeholder" until the conflicting claims of the surety and the trustee in bankruptcy were resolved..$^{90}$ The Court of Claims proposed a single question as outcome determinative-was the surety satisfying an obligation of the contractor to the United States ? $^{91}$ Answering in the affirmative, the court stated that though the Government did not promise to pay laborers and materialmen and the law did not give them a lien against federal structures in the event of nonpayment, the United States was not willing that they should go unpaid, and thus required of the contractor, as a condition for the award of the contract, a payment bond for the protection of suppliers. ${ }^{92}$ Based upon this requirement and the Govern-

16 (d) \& 17(a) (1958) ; set-off the amount owing the contractor against the damages arising on default, in accord with United States v. Munsey Trust Co., 332 U.S. 234 (1947); claim the Government's statutory priority under the Bankruptcy Act, see MACLACHLAN, BANKRUPTCX $\$ 145$, at 138-39 (1956) ; and, finally, assert rights under its own equitable lien or equitable priority.

85. 197 F. Supp. 441 (W.D.N.Y. 1961).

86. Id. at $442-43$.

87. Ibid.

88. See text at notes $68-77$ supra.

89. 169 F. Supp. 945 (Ct. Cl. 1959).

90. Id. at 946. The United States brought in the trustee in bankruptcy through a motion for intervention.

91. Ibid.

92. Id. at 946-47. 
ment's standard contractual provision obligating the contractor to pay laborers and materialmen, ${ }^{93}$ the United States acquired a right against the contractor to ensure such payment. ${ }^{94}$ Therefore, upon payment, the surety satisfied the twofold obligations of the contractor: first, to the laborers and materialmen who, the court made clear, are mere general creditors $;^{95}$ and second, to the United States, which is a preferred creditor because of its possession of funds that may be set-off against the amount due the defaulting contractor. ${ }^{96}$ Consequently, the surety, as a subrogee of the Government, recovered the fund to the extent of loss under the bond.

Continental's statement of the surety's subrogation to the rights of the Government is unique. For it, unlike other statements, establishes a clear doctrinal foundation for the rights of a surety in the field of public construction contracts. This court's theory constructs a quadrangle of rights and liabilities which rests on a duty impressed by the Government upon the contractor to secure the payment of laborers and materialmen through the furnishing of a payment bond and contractually covenanting to pay them. ${ }^{97}$ The Government can ensure the contractor's fulfillment of this obligation by retention of the fund as security, the contractor having mutually agreed with the Government that such payment would be accomplished. Upon payment, therefore, the surety benefits not only the suppliers, but also the Government as contractee, and is subrogated to the latter's right to utilize the fund to offset the damages arising upon default. ${ }^{98}$ Moreover, since the surety's right relates-back to the com-

93. Standard Form No. 23, 41 U.S.C. App., Rules \& Regs. § 54.13, Art. 17(a) (1958). But see note 97 infra as to the new standard contract.

94. 169 F. Supp. at 947.

95. Ibid.

96. Ibid.

97. The new Government construction contract, effective July 1, 1961, is silent as to the obligation of the contractor to pay laborers and materialmen. See Standard Form No. 23A, 26 Fed. Reg. 1050 (1961). The Miller Act Payment Bond continues to contain a provision that "the principal shall promptly make payment to all persons supplying labor and materials." See the United States form approved Sept. 16, 1935, Standard Form No. 25A, 41 U.S.C. App., Rules \& Regs. $\$ 54.16$ (1958). This bond covenant has been read into the prime contract by several courts so that breach of the bond is an effective breach of the contract with the United States. Martin v. National Sur. Co., 300 U.S. 588, 598 (1937). See Maryland Cas. Co. v. United States, 53 F. Supp. 436, 440 (Ct. Cl. 1944), where the court said:

[W] hen the surety pays the laborers and materialmen, it is performing the contract as much as when it completes the building.

See also Morgenthau v. Fidelity \& Deposit Co., 94 F.2d 632 (D.C. Cir. 1937). Consequently, even in the absence of a direct contractual duty toward the Government, the surety still satisfies an obligation, contractual in nature, owed by the contractor to the United States.

98. Martin v. National Sur. Co., 300 U.S. 588 (1937) ; Fidelity \& Deposit Co. v. Housing Authority, 241 F.2d 142 (2d Cir. 1957); In re L. H. Duncan \& Sons, 127 F.2d 640 (3d Cir. 1942) (failure to pay tantamount to breach of contract). Subrogation arises from the owner's right to have the original contract performed according to its terms, one of which is the direct contractual obligation to the Government, as contractee, binding the 
mencement of its obligation, the date of the bond, the surety's claim attaches to the fund in the form of an equitable lien that is defeasible only upon transfer of the fund to a bona fide creditor of the contractor taking without knowledge of its rights. ${ }^{99}$ Though this theory, incorporating the idea of an equitable lien, may seem the other side of the Henningsen coin, it is not similar. The interest of the Government as contractee is based on the same underlying equitable consideration which prevented the Government from leaving suppliers unsecured because of the happenstance of Government immunity from liens and the absence of direct contractual liability of the United States. But the Government's right to which the surety is subrogated is not the amorphous equitable one espoused in Henningsen; rather it arises from the provisions of the contract between the Government and the contractor. Under this theory the Government is solely an obligee, ${ }^{100}$ thus resolving the inconsistency of the Henningsen duality. Further, the disturbing absence of the Government's primary liability, evident in the Henningsen theory, is no longer of any consequence, for the Government is the beneficiary, rather than the obligor, of the contractual duty.

contractor and the surety to pay suppliers. Failure to meet this term constitutes a breach of contract upon which the Government, as owner-promisee in this donee beneficiary contract, and its subrogee become entitled to the withheld fund to the extent of loss. Atlantic Ref. Co. v. Continental Cas. Co., 183 F. Supp. 478 (W.D. Pa. 1960); Sundheim v. School Dist. of Philadelphia, $311 \mathrm{~Pa} .90,166$ Atl. 365 (1933).

99. Cf., Hamilton Fire Ins. Co. v. Greger, 246 N.Y. 162, 158 N.E. 60 (1927), merging wrongful release of a tortfeasor by an insured, characterized in PATTERSON, MANUAL FOR Teachers, Cases on Insurance 22 (3d ed. 1955) as an "equitable tort." As to the "equitable lien," similar only in result to the one formerly discussed, see note 82 supra and accompanying text.

100. Notwithstanding the statement in Belknap Hardware \& Mfg. Co. v. Ohio River Contract Co., 271 Fed. 144, 149-50 (6th Cir. 1921), that the Government's designation as obligee of the bond is solely for the convenience of claimants, the force of this "mere" designation becomes apparent. The Government, under the Continental theory by operation of law becomes a true obligee, rather than a mere formal one. See United States Fid. \& Guar. Co. v. Triborough Bridge Authority, 297 N.Y. 31, 74 N.E.2d 226 (1947). 